\title{
Fighting against climate change and for fair trade: finding the EU's interest in the solar panels dispute with China
}

\author{
Coraline Goron ${ }^{1,2}$ (D)
}

Published online: 8 March 2018

(C) The Author(s) 2018. This article is an open access publication

\begin{abstract}
The dispute between the EU and China regarding the trade in solar panels has been commonly explained in terms of power politics, whereby a mercantile China exploited European internal divisions to its advantage. But the trade defence case was also criticized for running against European climate policy goals. To which extent does this case illustrate a normative conflict between trade and the environment? The article replaces the dispute in the context of the trade defence procedures, according to which the EU had to decide, first, whether China's subsidization of its PV industry was illegal, and second, whether Europe's climate policies warranted against imposing trade defence duties. It finds that, in this case, the familiar competition between divergent European industrial interests was made worse by an important normative cleavage amongst European decision-makers, regarding the appropriate way to achieve global climate change policy goals. Simply applying the law did not settle the dispute. Instead, it plastered a political compromise emerged from a shift in the political narrative of the dispute, from emphasizing competition to emphasizing interdependence, pushing the Commission into a political compromise with China.
\end{abstract}

Keywords Anti-dumping · Energy subsidies · Photovoltaic energy · EU-China relations

Electronic supplementary material The online version of this article (https://doi.org/10.1007/s12689018-0080-z) contains supplementary material, which is available to authorized users.

Coraline Goron

C.C.F.Goron@Warwick.ac.uk

1 GEM Erasmus Mundus PhD School, Université Libre de Bruxelles (ULB), Brussels, Belgium

2 Warwick University, Coventry, UK 


\section{Introduction}

Climate change has been at the forefront of the EU-China strategic partnership for many years. The dominant rhetoric displayed in bilateral meetings and joint declarations has been one of cooperation, mutual benefits and joint efforts to address this global environmental threat. Therefore, the escalation of the solar panel antidumping case into a major trade dispute, which highlighted both the possible contradiction between the promotion of strategic industrial interests and the pursuit of common global climate goals, and the inadequacy of trade law to resolve it, attracted unprecedented attention.

The dominant narrative of this dispute initially drew from neo-mercantilist interpretations, ${ }^{1}$ where the EU and China were represented as defending incompatible economic interests by means of political pressures and threats of "trade war". Mainstream medias on both sides largely relayed this interpretation, which presented the EU and China as single entities competing for economic power globally. In Europe, they portrayed a bullish China playing divide and reign with the Member States, resulting in a European Union (EU) that was divided, and incapable of defending its commercial interests. ${ }^{2}$ The Chinese side accused the EU of abusing trade remedies to protect the dominant position of its PV industry. ${ }^{3}$

This article argues that the way in which economic interests played out in this dispute cannot be adequately explained with such framework, because it overlooks the internal divergence of economic interests and ignores the impact of global environmental interests. The trade defense case concerned photovoltaic (PV) cells and panels used to produce renewable energy, which is a core element of the European strategy to fight climate change. Environmental NGOs claimed that the action of the EU against cheaper Chinese solar panels in the name of fair trade ran against its global climate policy goals, echoing the concern spelled out by Naomi Klein in her book This Changes Everything: Capitalism versus the Climate that "our economic system and our planetary system are now at war." (Klein 2014)

These environmental arguments, which questioned international trade norms and practices, did not side with either the European or the Chinese position. What role did they play alongside industrial interest in the development of the dispute, and to which extent does this case illustrate a wider normative conflict between trade and environmental norms?

The paper replaces the dispute in the context of trade defence procedures carried out in the EU by the European Commission, which follow specific administrative rules partly derives from the global trade regime norms binding on the EU and China under the World Trade Organization (WTO). However, at the time of the dispute these global norms were contested, globally and within the EU. More precisely, the trade defence investigations

\footnotetext{
${ }^{1}$ Neo-mercantilism is a concept that refers to national policies that seek to manipulate trade to serve national interests. It is the opposite of global trade liberalization pursued under the GATT and the WTO.

2 Amongst many sources, see China Economic Review (2013).

3 For Bai Ming (Institute of International Trade and Economic Cooperation, Ministry of Commerce) China' bottom line was to firmly refuse EU's protectionism and abuse of trade remedies and firmly protect China's interest. Cited in Xinlangwang (2013).
} 
stumbled on two key normative issues: what does the global trade regime allow governments to do to steer the "low carbon economy?" And does the fight against climate change override the need for trade protection if it would come at the expense of achieving climate policy goals? The solar panel trade defence case turned into a wider political battle when several Member States confronted the European Commission over its proposals as to how to solve these disputes.

The core finding of the paper is that, as the dispute evolved, the legitimacy of the Commission's position on the legal case was challenged and a political compromise emerged outside of the trade defence procedures. It further argues that this political settlement was necessary to reconcile both divergent material interests and divergent norms within the EU, including those that should guide the transition towards a global, interdependent low carbon economy, where China plays a central role.

The rest of the paper develops this finding, based on a parallel analysis of the legal arguments and the broader political narratives involved in different stages of the dispute in the EU. The objective of this paper is to elucidate the evolving relationships between the divergent narratives built around industrial and environmental interests, which were also framed by the trade defence procedures. The empirical material reviewed includes legal and policy documents, news reports, industry papers, interviews as well as personal interactions with stakeholders in Brussels and Beijing in 2013 and 2014.

The first part traces the emergence of the different environmental arguments in and around the trade defence investigations, leading up to the radical change in the Commission's position in the second half of 2013. The second part analyses the Commission's handling of the environmental arguments in the trade defence case. It shows how the Commission's initial position became contested not only by Member States, but also by segments of the EU industry and civil society. The final part explores how divergent interests were finally reconciled, by showing how the initially dominant narrative of an unfair 'global green competition' between ruleabiding Europe and Mercantile China gave way to an alternative narrative of 'global green production', according to which the EU and China shared interests for better or worse.

\section{The divergent coalitions claiming to represent the European interest in the solar panel dispute}

\subsection{The internal politics of EU's trade defence: institutions and interests}

In September 2012, the European Commission announced the launch of an antidumping (AD) investigation into solar photovoltaic cells, wafers and modules imported from China. The case covered a trade value estimated at $€ 21$ billion in 2011, or roughly $4.8 \%$ of Chinese exports to the EU. It was thus 'the most significant anti-dumping complaint the European Commission had ever received' (EC 2012a). Investigations into countervailing duties (CVD) soon followed.

International tensions had been escalating since 2009 (Lewis 2014) and the United States (US) was already on the verge of imposing high-level tariffs against Chinese solar 
products. ${ }^{4}$ The company that led the campaign against Chinese solar PV in the US, the German manufacturer SolarWorld, formed a coalition of 6 PV producers, 'EU-Prosun', to demand parallel protection in the EU. In response, the Alliance for Affordable Solar Energy (AFASE) was formed to oppose the tariffs. By the end of 2013 AFASE gathered over 800 European companies, some of them with ties to Chinese companies (Curran 2015; Kolk and Curran 2017). ${ }^{5}$ These two competing coalitions represented different segments of the PV production chain. EU-Prosun represented manufacturers of solar wafers, cells and modules, while AFASE was a coalition of upstream producers (polysilicon and equipment exported to China) and downstream retailers and installers of PV projects. The European Photovoltaic Industry Association (EPIA), which had members on each side, refrained from taking side until the dispute was settled. However, by the time that the Commission had to decide whether or not to renew its tariff policy in 2015, it did take more clearly position against the tariffs that, according to its judgement, hurt the development of the PV industry in Europe (EPIA 2015).

Besides industrial interests, the political actors involved in the dispute were also divided. According to the EU's trade defence rules, the European Commission, as the executive agency of the EU Common Trade Policy, was in charge of conducting the investigations and propose remedies. But then, it had to convince the Council of Ministers representing the EU Member States to adopt the final AD and CVD remedies. ${ }^{6}$ As often in TDI cases, the Member States were divided internally and vis a vis the Commission's position. Whether contingent or ideologically motivated (Evenett and Vermulst 2005; Nordström 2011; Bollen 2016), ${ }^{7}$ the divisions sparked by the Solar Panel dispute were very salient and critically observed by the Chinese. ${ }^{8}$ Some governments opposed the tariffs from the outset. Importantly, Germany's Chancellor Angela Merkel announced in August 2012 that she wanted to solve the dispute politically, even though the main claimant Solarworld was a German company. ${ }^{9}$ The Swedish and UK governments also publicly opposed the tariffs.

\footnotetext{
${ }^{4}$ In October 2012, the US Commerce Department set AD ranging from 18.32 to $249.96 \%$ on solar cells and modules from China. By comparison, the U.S. case was much smaller than the EU: it covered imports estimated $\$ 2.1$ billion from China and \$513.5 million from Taiwan.

${ }^{5}$ Curran and Kolk have analysed the positions and ideological arguments of both coalitions in great details. In Curran's investigations, she also found that Trina Solar, China's most powerful PV producer, was the spokesperson for AFASE campaign and also its main financial supporter. Some could read this as influence, while others would see that it reflects the logical connection between the European companies and their Chinese supplier.

${ }^{6}$ This situation changes with the Lisbon Treaty (2009). The Member States no longer vote in the Council. Instead, they give a binding opinion to the Commission through an Examination Committee voting at qualified majority. However, these treaty changes were implemented only after the so-called Omnibus Regulation was adopted on 12 December 2013. Since the Solar Panel case was launched in September 2012, the old procedure still applied and the Council Members had to vote.

${ }^{7}$ Bollen demonstrates that there are major empirical and theoretical gaps in the research on how member states' preferences influence TDI cases.

${ }^{8}$ The newspaper Fenghuang Jingjinwang represents the mainstream Chinese view that the tariffs would hit the PV industry, PV costumers and threaten EU's energy security and energy strategy (2012). See also the academic discussion hosted by the European Studies Institute of the Chinese Academy of Social Science (CASS 2013).

${ }^{9}$ Germany was also the main exporter of polysilicon and manufacturing equipment to China's PV manufacturers.
} 
However, France, Spain, Italy and Portugal initially favoured protection. At the same time, the European Parliament, which only had a consultative role, held a couple of debates in which Members (MEPs) called for a strong defence of the EU's PV industry. ${ }^{10}$ For the Chinese, these divisions demonstrated the partiality of trade defence instruments lending support for the Chinese government's stern opposition to the tariffs. ${ }^{11}$

From the point of view of the Commission, the involvement of the Member States was perceived as a weakness just awaiting Beijing's exploitation. In response, it portrayed its role as 'to ensure independence and work on behalf of everyone across Europe by seeing the "big picture" (De Gucht 2013b). However, very different perspectives prevailed in many national capitals, where, as a commentator put it "the geopolitical relationship [with China] has become almost too important to national capitals to entrust to the commission" (Chaffin 2013).

\subsection{Tracing environmental arguments in the dispute}

The strategic importance of China and divergent economic interests were not the only reasons for which the Commission's claim to act on EU's behalf was challenged. From the outset, the Commission's action was contested because the tariffs were aimed at increasing the price of PV panels on the EU market, at a time when a core objective of climate policy was to make them competitive against fossil fuels and affordable to a majority of citizens. Indeed, the probe came against a backdrop of growing concerns about trade rules becoming barriers to meaningful action to combat climate change (Klein 2014; Lewis 2014). The unease in the Commission was evidenced by its unusual public statement within days after launching the probe, where it claimed that 'the EU's investigations into solar panel imports from China does not harm Europe's climate goals' (EC 2012b). This section provides an overview of how the dispute unfolded, and the main steps are summarized in Table 1.

In reaction, the Chinese government immediately announced a probe into European (mainly German) imports of polysilicon, which it used to manufacture the contested cells and panels. ${ }^{12}$ Soon, it also brought an action against Italian and Greek renewable feed-in-tariff policies at the WTO. These actions significantly broadened the scope of the trade dispute for EU member states, while also pressing the EU on the issue at the core of the dispute: the subsidization of low carbon technologies development by the state (see below). ${ }^{13}$

The issue of the sustainability of the energy transition also had a crucial employment dimension. Both the EU and China have repeatedly emphasized that the Energy transition is about growth and jobs. Yet, while EU-Prosun claimed that Chinese dumping threatened 25,000 industrial jobs (EU-Prosun 2012), a Prognos

\footnotetext{
${ }^{10}$ See for instance the oral Question to the Commission put by MEP Vital Moreira on behalf of the International Trade Committee (INTA), on 22 September 2012.

11 Interview with the Chinese Mission on 27.11.2014.

12 Ministry of Commerce of the People's Republic of China (Mofcom) Notices 71/2012; 70/2012. These cases, which are listed in Annex 1, have all been resolved through negotiations rather than adjudication.

13 WTO. Case DS452. 5 November 2012. This case was later abandoned.
} 
Table 1 Chronology of the EU-China solar PV dispute

\section{From trade defence to trade war: July 2012-August 2013}

25 July 2012

10 September 2012

26 September 2012

6 September 2012

26 September 2012

5 November 2012

8 November 2012

18 February 2013

28 February 2013

1 March 2013

27 April 2013

13 May 2013

15 May 2013

May 2013

30 May 2013

3 June 2013

5 June 2013

5 June 2013

June 2013

13 June 2013

27 July 2013

1st August 2013

6 August 2013
EU-Prosun fills AD complaint with the European Commission

The Commission releases a factsheet entitled 'Why the EU's investigation into solar panel imports from China does not harm Europe's climate goals'

EU-Prosun fills anti-subsidy complaint with the European Commission

The Commission launches AD investigations on solar panels (2012/C269/04)

EU-Prosun fills CVD complaint with the European Commission

MOFCOM launches probe into European polysilicon and puts requests for consultation at the WTO against Italian and Greek renewable policies

The Commission launches anti-subsidy investigations on solar panels (2012/C 122/17)

Prognos Study commissioned by AFASE on tariffs' impact on employment and value-added in the EU

The Commission launches AD investigation in solar glass from China (2013/C58/ 06)

The Commission imposes customs registration of PV cells and panels from China [Commission Decision (EU) No. 182/2013]

The Commission launches CVD investigation in solar glass from China (2013/ C122/17)

PWC publishes a critical review of the Prognos study

The Commission announces intention to open ex-officio AD and CVD probes into imports of mobile telecommunications networks from China. Memo/13/439

Consultations between the Commission and a delegation of the China Chamber of Commerce for Import and Export of Machinery and Electronic Products (CCCME) bring no outcome

WWF international, Natuur and Milieu, E3G and Change Partnership publish a position paper criticizing the Commission

AFASE launches an online petition to stop the imposition of duties

The Commission releases its preliminary findings on $\mathrm{AD}$ and impose provisional duties. Discount granted until 6 August. Commission Regulation (EU) No. $513 / 2013$

MOFCOM announces AD probe into EU wines

The Swedish National Board of Trade report criticizing the Commission

Court case filled by Chinese PV company DelSolar against the provisional AD duties (T-320/13) unsuccessful

The Commission agrees a price undertaking with China

Court case filled by EU-Prosun against the Commission's decision to suspend the application of provisional duties until 6 August. (T-393/13) unsuccessful

Entry into force of the price undertaking (Commission Decision 2013/423/EU)

The Détente-August 2013-December 2013

18 October 2013 Court case filled by EU-Prosun members against the Commission decision to accept the price undertaking. (T-507/13) unsuccessful

19-21 November 16th EU-China Summit Meeting themed "Green Growth"-Announce of the launch 2013 of negotiations of a comprehensive Investment Agreement 
Table 1 continued

$\begin{array}{ll}\begin{array}{l}24 \text { November } \\ 2013\end{array} & \begin{array}{l}\text { 4th EU-China High-Level Economic and Trade Dialogue (the first since 2010) } \\ 28 \text { November }\end{array} \\ \begin{array}{l}\text { The EU adopts provisional duties on imports of solar glass from China [Commission } \\ \text { Regulation (EU) No 1205/2013] }\end{array} \\ \begin{array}{c}\text { The EU adopts final AD and AS tariffs on PV cells and modules for 2 years. Wafers } \\ \text { are removed (Council Implementing Regulations Nos. 1238/2013 and 1239/2013) }\end{array} \\ \begin{array}{l}\text { The EU adopts a revised price undertaking to take account of the exclusion of } \\ \text { wafers. It covers 75\% of Chinese PV imports (2013/707/EU) }\end{array}\end{array}$

\section{Settlement of adjacent disputes-January 2014 to December 2014}

January 2014 China MOFCOM finds dumping of subsidized Polysilicon from the EU (Germany)

28 February 2014 Court cases filled by EU-Prosun members against the Final Regulation confirming the undertaking agreement (cases T-141/14 and T-142/14) unsuccessful

28 February 2014 Court cases filled by Chinese PV industries against the EU decision to adopt final AD and CVD tariffs (case T-157/14; T-158/14; T-160/14; T-161/14; T-162/14 and T-163/14) ongoing

18 March 2014 MOFCOM and German Polysilicon producer Wacker Chemie AG reach a negotiated agreement with a price undertaking

21 March $2014 \quad$ European and Chinese wine industries reach a political agreement. Termination of Chinese investigations

30 April $2014 \quad$ MOFCOM publishes its final AD and AS investigations against European solargrade polysilicon. Wacker Chemie AG is exempted thanks to the price agreement

13 May 2014

The EU adopts double AD and CVD tariffs on solar glass from China [Commission Decision (EU) No. 470/2014 and (EU) 471/2014]

5 June 2014 EU-Prosun fills a complaint with the Commission for violations of the price undertaking

20 October 2014 The Commission and the Chinese government settle the telecom case at EU-China Joint Committee

10 December The Commission confirms the methodology for adapting the minimum import price 2014 of Chinese solar cells and modules, challenged by EU-Prosun

\section{Implementing the price agreement and the future of the tariffs}

29 Januray 2015 EU-Prosun fills a request to revise the MIP based on a challenge of the Bloomberg price benchmark

27 April $2015 \quad$ EPIA, the European Photovoltaic Industry Association, officially takes position against the EU trade Defence measures

29 April $2015 \quad$ EU-Prosun fills a circumvention complaint for solar products from Malaysia and Taiwan

29 May $2015 \quad$ European Commission opens Circumvention investigations for solar products from Malaysia and Taiwan

4 June $2015 \quad$ European Commission withdraws the price undertaking for Canadian Solar, ET Solar and Renesolar on basis of circumvention. Implementing Regulation (EU) 2015/866

July 2015

Open Letter signed by 50 European Solar Companies on a "Solar Market Without Trade Barriers" under the leadership of the Solar Alliance for Europe (SAFE)

18 August 2015 European Commission withdraws the price undertaking for ZNSHINE on basis of circumvention. Implementing Regulation (EU) 2015/1403 
Table 1 continued

11 November European Commission withdraws the price undertaking for Chint Solar and Sunny 2015

Energy on basis of violation. Implementing Regulation (EU) 2015/2018

5 December 2015 Opening of expiry Reviews of AD and AS measures. 2015/C405/8, 5.12.2015 and 2015/C405/09, 5.12.2015

Opening of partial Interim Review on AD and AS measures against Solar Cells, which have stopped being produced in the EU and need to be imported.

2015/C405/10, 5.12.2015

5 December 2015 Launch of the Global Solar Council in Paris in the aftermath of COP 21

28 January 2016 European Commission withdraws the price undertaking for Trina Solar and its different subsidiaries on basis of circumvention. Implementing Regulation (EU) $2016 / 115$

6 February 2016 The Commission terminates the interim review of the MIP initiated in January 2015, concludes that there is no reason to modify the benchmark. (EU) 2016/12, L4/1, 7.1 .2016

11 February 2016 The circumvention investigations conclude to extend the AD and AS duties in force against China to solar panels and solar cells consigned from Taiwan and Malaysia. (EU) 2016/185. 12.2.2016 and (EU) 2016/184, 12.2.2016

study commissioned by AFASE in 2013 claimed that the tariffs could cost up to 218,000 jobs in the renewable energy sector (Prognos 2013). Nonetheless, in March 2013 the Commission imposed the registration of solar PV imports from China, which was interpreted as a signal that it would impose tariffs. The Commission concomitantly launched a probe into Chinese imports of solar glass. During his visit to Europe immediately after this imposition, Chinese Premier Li Keqiang and Chancellor Merkel jointly criticized the Commission's action and reiterated their resolve to settle the dispute politically.

The position of the Commission became increasingly contested within Europe, notably by a group of environmental NGOs, who denounced this 'rude and fully undeserved action' as 'the last thing that Europe needed to address climate change' (WWF et al. 2013). But the tug of war nonetheless kept escalating. Trade Commissioner Karel De Gucht announced his intention to launch and ex officio probe (without official industry complaint) into Chinese telecom services (De Gucht 2013a) and attempts to negotiate by a delegation of Chinese industries in May, ahead of the release of the Commission's AD investigations findings, were rejected. ${ }^{14}$ When the Commission announced in June that it had found ample evidence of dumping from the Chinese exporters and proposed to impose provisional duties between 37.3 and $67.9 \%$, only 4 Member States voted in favour, while 18 voted against and five abstained (Choudhury 2013; Shi 2013).

However, Trade Commissioner De Gucht, to show his determination, decided to use his legal prerogative and impose the provisional duties. ${ }^{15}$ Some governments reacted strongly against this unilateral action, even though De Gucht claimed that he was acting to protect the Member States who feared retaliation from China (Chaffin

\footnotetext{
${ }^{14}$ MOFCOM. Timeline: China-EU, Chin-US tug of war on solar duties. http://english.mofcom.gov.cn/ article/zt_solar/column2/201307/20130700218603.shtml. Accessed on 16 April 2016.

15 The vote of the Member States was only consultative at the provisional stage.
} 
2013). Remarkably, the British Energy Minister Greg Barker made a special trip to Brussels to vent his government's anger at a move, which, according to him, hurt the British PV sector (exports of manufacturing machinery to China and downstream PV installers). The German Chamber of Industry called for a swift ending of the 'trade war' after over a thousand PV companies petitioned the EU Commission not to impose tariffs, ${ }^{16}$ and the Swedish Board of Trade published a report entitled 'Targeting the Environment', where it denounced the negative consequences of the Commission's trade defence practice for climate policy.

China retaliated, as it had warned, by opening a probe into European wines (especially French). ${ }^{17}$ It made clear that if the EU really went ahead with high tariffs against the Chinese industry, it would not go undamaged. ${ }^{18}$ Concerns began to mount within the EU that the Commission's strategy to pressure the Chinese authorities would spill out of control and cause long damage to the bilateral relation (Martin 2013). By mid-July, even more Member States seemed inclined to vote against the final measures scheduled in December. ${ }^{19}$ Meanwhile, the Commission granted a temporary discount at $11.8 \%$, until the official publication of AD duties on 6 August, to help facilitate the negotiations of a deal with the Chinese PV industries. This decision was immediately challenged (though unsuccessfully) by EU-Prosun, who denounced a "manifest error of assessment of the facts" by the Commission and a "serious violation of its duty of care and good administration". 20

The de-escalation process started with the negotiation of an amiable "price undertaking" 21 following two weeks of negotiations in Beijing in July 2013. The negotiated settlement received almost unanimous support by the Member States, even though the minimum import price agreed was substantially lower than what the Commission initially proposed (Solar Server 2013). ${ }^{22}$ The Chinese accepted the deal, instead of gambling on a better outcome when the Member States' final vote came in December. ${ }^{23}$ Commissioner De Gucht justified the decision in the light of the global nature of the PV industry (De Gucht 2013c). But EU-Prosun was enraged by what it denounced as a "dumped price" (EU-Prosun 2013). It brought a series of (thus far unsuccessful) judicial actions, denouncing a lack of due process and

\footnotetext{
16 The letter was reported by the specialized PV magazine and the Chinese media, such as the Nanfang Ribao.

17 Mofcom Notice No. 2013/36 and 2013/37. Rumors also reported lobbying actions towards smaller Central and Eastern Europe Member States (Interview, 2 December 2014).

18 According to Mofcom's Bai Ming, Premier Li Keqiang was determined to do everything possible to avoid the tariffs and get a win-win deal with the EU. Xinlangwang (2013).

19 Portugal, which had been a supporter of the duties, was reverting its position, Interview, Brussels. 24 September 2013.

${ }^{20}$ EU-Prosun action was dismissed by the General Court (case T-393/13) also on appeal (case C-312/15 $\mathrm{P})$.

21 Price undertakings are minimum import conditions that Chinese exporters agreed to abide by when selling their products to the EU.

22 The minimum import price was set at €0, 56/WP for modules and 0.29€/WP for cells. According EUProsun, this required "almost no concession" from the Chinese manufacturers, even with import quotas of $7 \mathrm{GW}$ and $2.3 \mathrm{GW}$ per year, respectively (roughly 60-70\% of the expected EU market in 2013).

23 Interview Chinese Embassy. 27.11.2014.
} 
transparency in the negotiation of the price undertaking and the fact that it was, according to them, "manifestly inadequate" to remove the injury to EU producers. ${ }^{24}$

The political 'détente' nevertheless continued throughout the autumn. The Commission decided to follow the usual practice under the 'lesser duty rule' ${ }^{25}$ of subsuming CVD tariffs duties under the price agreement, even though Commissioner De Gucht would have preferred to forego this practice in cases involving what he called 'capitalist states' like China (De Gucht 2013d). The EU-China annual summit on 19-21 November, themed "Green Growth", celebrated the diplomatic victory, resumed bilateral high-level trade dialogue, which had been suspended for 3 years, and even launched the negotiations of a bilateral investment treaty (Xinhua 2013a, b; Van Rompuy 2013). Finally, the official adoption of AD and CVD measures in December eliminated wafers from the scope of the probe and reduced the length of the measures to 2 years instead of the normal five, because of the 'volatility in the sector' (the very rapid decrease in global PV prices). ${ }^{26}$ The Commission abandoned the threatened probe into Chinese telecoms (EC 2014), while the Chinese probes into German polysilicon and French wine rapidly found settlements. ${ }^{27}$ Beijing did not press further on its WTO actions against European feed-in-tariffs policies and quietly accepted the EU imposition of double AD and AS tariffs on its exports of solar PV glass.

In short, although direct actions by the Chinese government did enrage some European governments, overall it fails to fully explain why Europeans were so publicly divided and why the Commission changed its position so radically. Disagreements on the impact of $\mathrm{AD}$ and CVD on Europe's green growth goals, including whether fighting China was the appropriate strategy to achieve them, contributed to 'outflank' the trade Commissioner (Chaffin 2013). This sets the solar panels dispute apart from the many other trade disputes with China. ${ }^{28}$

\section{The demise of trade rules as the arbiter of European interests in the solar PV case}

The EU's trade defence cases against China have been amongst the most challenging and controversial, due to the application of the "non-market economy status" rules (Snyder 2001; Vermust and Gatta 2012). This section examines how, in

\footnotetext{
${ }^{24}$ EU-Prosun action against the Price Taking Agreement itself was considered inadmissible (Case T-50713, C-142/15P). EU-Prosun then requested the annulation of the articles in the final AD and CVD regulations referring to it, but were dismissed on ground of non-severability (cases T-141/14 and T-142/ 14) Their appeal is still pending (cases C-204/16 P and C-205/16 P).

25 The Lesser Duty rule refers to a practice of the EC to lower the total remedy to a level sufficient to remove the injury, when it appears to be lower than the dumping or subsidy margin.

26 Solar wafers, which are slices of crystalline silicon, were ultimately withdrawn on the ground that it was a different product from cells and modules, which can produce electricity.

27 Mofcom Notice No. 7/2014 and European Commission (2014) settling the dispute on polysilicon with a price agreement agreed with the main German exporter Wacker Chemie AG; Mofcom Notice 2014/19 and (wine).

28 In 2013 the EU had 50 anti-dumping measures and one anti-subsidy measure in force against Chinese imports.
} 
the solar panel case, trade defence procedures became additionally politicized by environmental arguments, and how this contributed to undermining the Commission's legitimacy as the institution responsible for applying trade rules fairly and to Europe's best interest. The arguments are summarized in Table 2.

\subsection{Determining the fair level of government intervention in the green economy}

The central claim made by EU-Prosun was that Chinese PV manufacturers could dump their products on the EU market because of the aggressive industrial policies of the Chinese government (EU-Prosun 2012). This issue was central to the whole dispute. Yet, the fact that government support for renewables could be considered illegitimate under international trade rules was itself controversial. Moreover, the action seemed inconsistent with the praise that China received in climate circles for its unprecedented and unmatched efforts to build a renewable energy capacity and for lowering the costs of these technologies. Yet, as mentioned above, the dispute broke against the background of an important legal controversy about the incompatibility of support programs for renewable energy with global trade law, which seemed at odds with the claims by the self-same governments that they were committed to combat climate change (Wilke 2011; Lewis 2014).

Different types of subsidies are those given to producers and those given to consumers. One major issue brought to the WTO concerned the help provided to consumers through "feed-in-tariffs". But the DSB Appellate Body's first ruling in the pioneer Canada Renewable Energy ${ }^{29}$ case (2013) only decidedly concluded on the illegality of "local content requirements" in Canada's Feed-in-Tariff, but declined to conclude on whether Feed-in-Tariffs schemes actually qualify as subsidy.

However, the subsidies provided to producers were even more likely to be considered countervailable under WTO law and pose a challenge from the point of view of the promotion of environmental goods (Rubini 2011). A nuanced view on this problem was that

It would be clearly inacceptable if one country was proven to benefit economically at the expense of others from industrial policies that violate WTO rules. But it would similarly be unacceptable if current WTO rules prevented the kind of government intervention needed to efficiently fight against climate change, bearing in mind the need for urgent action (Guérin and Schiavo 2011).

And yet, in the solar panel case, the Commission examined the situation of China's PV industry without consideration for their environmental value. It found that 'the PV industry in the PRC receives preferential treatment ${ }^{30}$, amounting to an average aggregate subsidy margins of $6.4 \%$, by applying a similar methodology as

\footnotetext{
${ }^{29}$ Canada-Certain Measures Affecting the Renewable Energy Generation Sector. Appellate Body Report WT/DS412/AB/R/WT/DS426/AB/R, 6 May 2013.

${ }^{30}$ Solar cells and modules from China (CVD) Council Implementing Regulation 1239/2013 § 101, 474.
} 
in the 2011 Coated Fine Paper Case,$^{31}$ its first concurrent AD and AS investigations against China.

A crucial elements of AS cases in general is the necessity to establish the specificity of the targeted measures for them to give rise to lawful countermeasures. The Agreement on Subsidies and Countervailing Measures (SCM Agreement) specifies that only measures that specifically benefit to a certain enterprise, group of enterprises, industry or specific territory can give rise to legal protection if they cause arm to foreign markets.

In the solar panel case, the Commission applied the same broad interpretation of specificity it had adopted in the in the 2011 Coated Fine Paper Case. More precisely, only one of the subsidies investigated by the Commission was specifically targeted at the solar PV industry: the 'Golden Sun Demonstration Programme' (金 太阳示范工程, jintaiyang shifan gongcheng), which it considered a de facto (though negligible) subsidy, because in some cases it found evidence that solar demonstration projects' grants had been paid directly to the PV manufacturers instead of the solar power producers. ${ }^{32}$ The rest of the subsidies reviewed by the Commission could have applied similarly to a range of other industrial sectors targeted for development in Chinese policy documents. They included, for instance, preferential loans afforded by Chinese state-owned commercial and policy banks to the category of 'encouraged' industries' ${ }^{33}$; preferential export credit insurances afforded to 'certain enterprises', as well as various tax breaks granted to 'foreign investment firms' and 'New-Technology Enterprises'; dodgy land acquisition deals were also included, even though the evidence and methodology to quantify them was contested. ${ }^{34}$ This interpretation by the Commission was in line with that adopted by the United States in several anti-dumping cases against Chinese imports, which was validated by the WTO panel and Appellate Body ruling in the 2011 case US-Anti-Dumping and Countervailing Duties (China), ${ }^{35}$ but this interpretation has been criticized by trade lawyers who wondered what then would not be construed as an actionable subsidy (Vermust and Gatta 2012).

Politically, the Commission's battle against China's 'capitalist state' was largely supported domestically by governments and the European Parliament. On other

\footnotetext{
31 Council Implementing Regulation 452/2011, Coated Fine Paper from China, Official Journal of the European Union (OJ) 2011 L128 (definitive countervailing duty); Council Implementing Regulation 451/2011, Coated Fine Paper from China, OJ 2011 L128 (definitive anti-dumping duty).

32 According to individual treatment, out of 7 sampled companies, the subsidy amount calculated varied from $0 \%$ for 4 of them to $0.35 \%$ (maximum).

33 Policy under Decision No. 40 of China's State Council (2005) concerned with "Promoting the Industrial Structure Adjustment", e.g. promoting new technologies.

34 To calculate the subsidy, the Commission used Taiwan's land prices. For loans, it used a "constructed price". Both techniques were permitted by the TDI regulations and the WTO because of China's nonmarket economy status, which is due to expire in December 2016. The use of these methodologies was nonetheless contested by Chinese producers (cases T-157/14, T-160/14, T-161/14, T-162/14, and T-163/ 14), who believed that it inflates the dumping margin. Interview Chinese Embassy 27.11.2014.

35 The Appellate Body upheld the Panel's findings that the fact that large segments of industry were broadly targeted by Chinese industrial policy documents to receive preferential loans, or the fact that certain economic zones received preferential conditions, or that land rights provisions, were specific in the meaning of article 2.1 of the SCM agreement. WT/DS379/AB/R para 401, 414, 424.
} 
Table 2 Arguments of different parties on the "green subsidies" and the definition of the union interest

\begin{tabular}{|c|c|c|}
\hline & Subsidies & Union interest \\
\hline $\begin{array}{l}\text { European } \\
\text { Commission }\end{array}$ & $\begin{array}{l}\text { Pervasive subsidies afford an unfair } \\
\text { advantage to the Chinese industry }\end{array}$ & $\begin{array}{l}\text { Excludes climate policy, limited to } \\
\text { ensuring that there is no compelling } \\
\text { reason that TD measures would } \\
\text { disproportionately hurt other market } \\
\text { segments }\end{array}$ \\
\hline China & $\begin{array}{l}\text { Chinese PV manufacturers are globally } \\
\text { integrated and essentially operate under } \\
\text { market conditions }\end{array}$ & $\begin{array}{l}\text { The EU's interest warrants against 'green } \\
\text { protectionism' }\end{array}$ \\
\hline EU-Prosun & $\begin{array}{l}\text { Chinese PV manufacturers receive unfair } \\
\text { support and are shield from market risks } \\
\text { by the government }\end{array}$ & $\begin{array}{l}\text { European manufacturers are the EU } \\
\text { interest because of their innovation } \\
\text { capacity and their potential for global } \\
\text { industrial leadership }\end{array}$ \\
\hline AFASE & $\begin{array}{l}\text { The PV industry needs policy support to } \\
\text { develop }\end{array}$ & $\begin{array}{l}\text { the Union interest should include climate } \\
\text { policies and cheap PV panels }\end{array}$ \\
\hline ENGOs & $\begin{array}{l}\text { Subsidies for green technologies is } \\
\text { necessary, trade dispute arm global } \\
\text { climate cooperation }\end{array}$ & $\begin{array}{l}\text { Climate change is part of the EU interest } \\
\text { and should be balanced against trade } \\
\text { interest }\end{array}$ \\
\hline
\end{tabular}

issues, such as the dumping of steel or the refusal to grant China Market Economy Status, the Member States were unanimous in resisting to Chinese pressures. But in the solar panel case, the environmental dimension of the goods at stake undermined this legal approach. Hence, the environmental lobby worried that if the EU, the US and potentially others applied such broad definition of subsidization to call into question each other's renewable policies, it would undermine the efforts deemed necessary to support the deployment of renewable energy, and foreclose the kind of policy measures that some pioneer European governments had used in the past and which included not only Feed-in-tariffs programs, but also widespread tax and regulatory support measures (Rubini 2011; Lewis 2014; Kolk and Curran 2017). At that time, anti-subsidy cases were very rare and nobody had thought to contest the legality of these policies, even as the companies that benefited from them expanded globally.

Grau et al. (2011) and Dunford et al. (2013) for instance demonstrated how German industrial policies, using public grants and preferential treatment, had supported the expansion of the pioneer German PV manufacturing in the 1990s and 2000s. Ironically, the beneficiaries included Solar AG, which later became Solarworld, the main plaintiff in the EU-China solar dispute. But whereas 'a cheeky Chinese policymaker could make much of European state intervention' (Evenett 2013), the adequacy of the policies that EU member states could adopt to support the growth of the renewable energy sector was at the core of EU's internal debates on how to implement EU renewable energy targets, which were ongoing at the time of the dispute (Buchan and Keay 2015; Goron and Freeman 2017). The solar panel case notably resonated with the worries expressed by European environmental NGOs' in that context, that a strict application of the EU's liberal State Aid rules (which are stricter than WTO rules to avoid distortions on the 
internal market) was undermining EU's ability to do precisely what the Chinese seemed able to do to support the development of its renewable energy industry. ${ }^{36}$

\subsection{Trade defence, climate change policy and 'the union interest'}

Whereas the Commission's findings on Chinese subsidies were in line with the WTO ruling, but debatable with regards global Climate Change policy goals, they had no direct implications for the EU's domestic PV market. However, AFASE also claimed that tariffs would significantly and adversely impact the development of Europe's PV market, and thereby impede on its ability to achieve its climate policy targets. Their core argument was that the tariffs would increase the price of PV cells and panels in the EU market and decrease the demand from costumers already weakened by the withdrawal of support schemes in several EU countries (notably in Spain, Buchan and Keay 2015). According to them increasing the cost of renewables on the EU market contradicted EU's climate change policy objectives.

The inability of the anti-dumping proceedings to address these concerns adequately probably more directly contributed to the politicization of the case and the necessity to settle it through negotiation.

AFASE's claim was addressed under a unique provision in the EU trade defence regulations, according to which the Commission must verify that the imposition of $\mathrm{AD}$ or AS measures would not run against the EU 'general interest'. ${ }^{37}$ As the Commission enjoys wide administrative discretion in interpreting this provision, which does not exist in WTO trade law, the different parties strived to convince the Commission to share their definition of what constituted this 'Union Interest'.

The argument of AFASE was that the 'Union Interest' should include climate policies. The Swedish National Board of Trade shared this interpretation, which it argued stemmed from the Lisbon treaty provisions, according to which the EU's common commercial policy must be conducted 'in the context of the principles and objectives of the Union's external action, which include environmental objectives (SNBT 2013). This approach, however, entailed a significant change in the Commission's classical application of this provision, which specifically excluded considering wider policy aspects (EC 2013a) and merely consisted in "balancing the economic interests of the different operators on a given market", with the presumption that only compelling reasons could justify not imposing tariffs once dumping was found (Vermust 2005).

The Commission upheld this classical approach and dismissed AFASE's interpretation. Therefore, it construed climate change policy narrowly, mainly as the interest of downstream industries and European consumers. It concluded that 'the overall positive effects [of the duties] for the union industry (solar PV manufacturers) outweigh the likely negative impact on other operators on the PV

\footnotetext{
36 The state aid rules were revised to bring more flexibility to the Member State's use of state aid "granted for environmental protection or energy objectives" (European Commission Guidelines on State aid for environmental protection and energy 2014-2020, para. 13, COM 2014/C200/01).

37 This provision is found in Article 21(1) Council Regulation No 1225/2009 (AD) and Article 31(1) Council Regulation No 597/2009 (CVD). It is an addition in EU from WTO obligations.
} 
market including end-users. ${ }^{38}$ More precisely, it denied that a plausible price increase for PV panels on the European market would affect demand for renewables. On the contrary, it concluded that it would be partly absorbed by operators and that the deployment of renewable energy would not be affected because (ironically considering the arguments on subsidies examined above) it relied also on policies that shielded it from fluctuations in market prices. It further argued that demand for solar energy would not be curtailed because the tariffs would improve the situation of the EU industry, who could ramp up production, lower prices and meet rising demand. ${ }^{39}$

It must be underlined that such conclusions endorsed a contested appreciation of the development of the European solar energy market. Premised on the belief that unfair subsidies and dumping had caused EU industry's dramatic decline ${ }^{40}$ and not, for instance, the withdrawal of support policies or problems within EU's PV manufacturing industry itself as AFASE argued, it assumed that the status quo ante would be instantly restored with the imposition of tariffs. Other segments of the PV industry and final consumers could not avail themselves of the 'Union Interest' provision to overturn the investigators' conclusion that trade defence measures were necessary to resist Chinese dumping.

\section{Green competition versus global green production: different narratives of a climate friendly trade regime}

These conclusions reached by the Commission's AD investigations could have led it to impose high-level tariffs, following the precedent set by the US and its own preference for sending a 'strong' message to China, as the imposition of interim measures despite the Council's majority opposition showed. Yet, the solution finally adopted was a price undertaking negotiated with Chinese exporters, even though this legal option was reputed for being difficult to enforce in China (Steinbach 2014). ${ }^{41}$ This section aims to demonstrate that this compromise emerged from the fact that, in the politics leading to resolution of the dispute, the narrative of 'global green competition', with which the Commission's findings became identified, progressively lost ground in favour of a 'global green production' narrative. These alternative narratives are summarized and displayed in Table 3.

\footnotetext{
38 This argumentation can be found in the provisional AD regulation published in June 2013 (OJ L152) § 259.

39 Idem § 257-259.

40 Chinese companies challenged the Commission's weak consideration of domestic factors.

41 Steinbach shows that the EU has been reluctant to use price undertakings in cases against China because of difficulties to monitor their implementation and cooperate effectively with Chinese authorities to enforce them. The price undertaking was subsequently withdrawn for several Chinese companies who violated the agreement (see the chronology for details). A circumvention case led to the extension of the TDI measures to PVs and cells consigned in Taiwan and Malaysia in 2015.
} 


\subsection{Green competition: zero sum game in the competitive global green economy}

The scenario that dominated European discussions in September 2012 portrayed the EU and China as competitors embarked in a zero-sum game race for green markets. In a context of souring trade relations, Members of the European Parliament for instance urged the Commission to 'send China a strong message' that it would defend its industry and would not 'let it threaten its businesses with retaliation'. ${ }^{2}$

EU-Prosun claimed that Chinese exporters had lowered markets prices to such a level that European manufacturers could not sustain the competition. The Commission's investigations indeed showed that Chinese PV production, which was virtually inexistent in 2005, had ballooned to account for about $60 \%$ of global production in 2011. Meanwhile, it estimated that less than $10 \%$ of this production was sold in China and 70\% was exported to Europe, where market demand was supported by feed-in-tariffs in several Member States. For EU-Prosun, this meant that 'European taxpayers money was used to ramp up solar panel production in China'. ${ }^{43}$ According to the Commission's findings, between 2009 and 2011 the share of EU's market taken by Chinese companies had increased from 63 to $80 \%$ for modules and $8-25 \%$ for cells.

Another key argument of EU-Prosun was about 'jobs', a major concern for EU leaders in the aftermath of the economic crisis. It argued that 25,000 industrial highend jobs in research and skilled production were threatened as European manufacturers closed doors. Moreover, as noted by Curran (2015), even more compelling was the argument that, ultimately, what was at stake was the preservation of Europe's competitiveness in the global green economy. Without manufacturing capacity, EU-Prosun spokesperson Milan Nitzschke argued, Europe would lose its innovative capacity to China, who would enjoy a de facto global monopoly (Nitzschke 2013). The chairman of the Parliament's international trade committee relayed this view when he argued that: "the devastating Chinese competition is also affecting some of the European Union's most innovative industries, including the solar panel industry" (Moreira 2012). The "Green competition' narrative build on the broader economic challenges that some Europeans identified with the rise of China (INTA 2012; De Gucht 2013b).

As for global climate change, this narrative emphasized that China's unfair trade practices were harmful to the global PV industry development. By 2013 the Chinese production capacity alone amounted to $150 \%$ of global consumption (EC 2013b). The sharp fall in European PV prices, from 2100 EUR/kW in 2009 to merely 764 EUR/kW in $2011,{ }^{44}$ was presented by EU-Prosun as a "race to death" provoked by

\footnotetext{
42 See for instance the intervention of Green MEP Yannick Jadot, posted in the EU Energy Briefing of 29 May 2013. http://www.vieuws.eu/brussels-briefings/brussels-briefing-energy-may-2013/. Accessed on 16 April 2016.

43 This argument by EU-Prosun campaigners (Interview Mark Dober. 2.12.2014) of a fortuity causeeffect between EU renewable policies and Chinese industrial policies was discussed in the Commission.

44 Commission's AD findings $§ 138$.
} 
Table 3 Green discourses and the solar panel dispute

\begin{tabular}{|c|c|c|}
\hline & Green competition & Global green production \\
\hline \multicolumn{3}{|c|}{ Position on relevant issues } \\
\hline $\begin{array}{l}\text { Green } \\
\quad \text { subsidies }\end{array}$ & $\begin{array}{l}\text { Chinese government subsidies create a } \\
\text { global monopoly, arm the healthy } \\
\text { development of the PV industry }\end{array}$ & $\begin{array}{l}\text { Green technologies can best develop by } \\
\text { using the comparative advantages of } \\
\text { different countries along the production } \\
\text { chain to ensure economies of scale and } \\
\text { lower prices }\end{array}$ \\
\hline Dumping & $\begin{array}{l}\text { Dumping causes irreparable injuries to } \\
\text { European industrial leadership, } \\
\text { undermining prospects for future green } \\
\text { growth }\end{array}$ & $\begin{array}{l}\text { The best way to avoid injury to the EU } \\
\text { industry is to build market capacity in } \\
\text { China and accelerate the global low } \\
\text { carbon transition }\end{array}$ \\
\hline Jobs & $\begin{array}{l}\text { High-end jobs in engineering and high-end } \\
\text { manufacturing are lost to the Chinese, } \\
\text { which threatens long-term prospects of } \\
\text { green growth in Europe }\end{array}$ & $\begin{array}{l}\text { EU PV jobs in innovation, and installation } \\
\text { and service are threatened by the duties, } \\
\text { while basic manufacturing anyways is } \\
\text { uncompetitive }\end{array}$ \\
\hline \multicolumn{3}{|c|}{ Preferred solution to the dispute } \\
\hline & $\begin{array}{l}\text { Protection of European industry; revival of } \\
\text { an assertive European industrial policy }\end{array}$ & $\begin{array}{l}\text { Free trade agreement on environmental } \\
\text { goods; enhanced international on market } \\
\text { access and S\&T cooperation }\end{array}$ \\
\hline \multicolumn{3}{|c|}{ Solution to the conflict between environment and trade } \\
\hline & $\begin{array}{l}\text { The environment is best protected when the } \\
\text { European industry is protected from } \\
\text { "unfair" competition and an } \\
\text { unsustainable "race to the bottom" in } \\
\text { production costs is avoided }\end{array}$ & $\begin{array}{l}\text { Trade disputes and disruptive protective } \\
\text { border measures must be avoided because } \\
\text { they create risks for the infant renewable } \\
\text { energy industries, which already must } \\
\text { compete against entrenched fossil fuels } \\
\text { interests }\end{array}$ \\
\hline
\end{tabular}

the irresponsible behaviour of Chinese manufacturers. ${ }^{45}$ Consequently, the EU's action was portrayed as the best strategy to rescue the global PV industry. Commissioner De Gucht affirmed that

Even those arguing that cheap solar panels are good for sustainable energy and the environment must realize that you need to keep the solar panel industry 'sustainable' in the first place if you are going to see any benefits over time. (De Gucht 2013b).

\subsection{Global green production: embracing the green "world factory"}

These were compelling arguments, especially since the Chinese PV industry recognized that it suffered from serious overcapacity problems domestically, which were already leading to large numbers of bankruptcies (Gao 2012; Economic Observer 2013). Nonetheless, AFASE and others thought that protectionist interests had profoundly misunderstood the structure of the emerging PV market, and offered a simplistic solution to the wrong problem in their attempt to foster Europe's

\footnotetext{
45 Interview with Mark Dober. 2.12.2014.
} 
leadership in the low carbon era. In fact, the most powerful arguments against the tariffs came from experts in the global PV industry itself. For instance, according to one of them

SolarWorld and the six other filers are shooting the solar industry in the foot we are shooting ourselves in the foot. (...) Because the solar industry is so internationally interconnected. (Brown 2013).

This sentence typically illustrates what is called here a 'green global production' narrative, which argued that tariffs would only damage competitive segments of the European PV industry and curtail the potential offered by economic globalization to scale up solar energy markets in time to address climate change (Green 2011). The Swedish Board of Trade for instance argued that

The EU's TDI measures on renewable energy sources are clearly acting in opposition to the goals of the EU's climate policy, which recognizes the potential in creating an open, competitive and demand-driven renewable energy sector (SNBT 2013).

This argument was supported by several academic analyses besides those provided by AFASE. They first emphasized the highly-fragmented nature of the PV production chain at the global level (Grau et al. 2011; Gallagher and Zhang 2013). In this chain, moreover, they pointed out that while Chinese companies dominated the manufacturing segment, European, Japanese and American firms were still largely dominant in most other segments, including R\&D and expensive manufacturing equipment (Dunford et al. 2013; Gallagher and Zhang 2013). Unsurprisingly, then, equipment manufacturers in England lobbied their MEPs and the government to voice their concerns about the duties in Brussels (Watson 2012). ${ }^{46}$ Commissioner De Gucht acknowledged this challenge as a principal reason for the EU to accept a price undertaking agreement in August 2013 (De Gucht 2013d).

Another dimension of this situation was that, according to Gallagher, most Chinese PV technology had been purchased, in the form of licenses, from western technology providers who continued to draw down substantial dividends while maintaining their technological edge (Gallagher 2014). Furthermore, these studies stressed the extreme sensitivity of the global PV sector to both financial markets and policy signals compared with the established fossil energy industries (Curran 2015). ${ }^{47}$ Thus, they argued that the EU tariffs would hit harder the most 'freemarket' oriented companies in China and perversely consolidate the Chinese PV industry around companies-like the bankrupt Suntech-who did benefit from obvious local political support. ${ }^{48}$

\footnotetext{
${ }^{46}$ MEP Graham Watson's Newsletter of 8 February 2013 elaborates on these concerns (Interview, 26.11.2014).

47 Chinese PV companies drew much resources from international finance. For instance, Suntech, Yingli, Trinasolar, Solarfun listed on New York Stock Exchange and Trinasolar, Solarfun, JA Solar and China Sunergy listed on Nasdaq.

48 For a detailed account of the Suntech 107 Billion Yuan debt problem for Wuxi City government, see Wang You's article in Caijing (2013).
} 
AFASE also had strong arguments on jobs. According to the study they commissioned from Prognos, duties threatened up to 200,000 jobs in competitive segments of the industry across Europe (Prognos 2013).

At a time of declining demand for solar PVs in Europe, a simultaneous crisis of Chinese over-production (Xie 2013; Laurent 2013) and rapidly falling production costs regardless of dumping, the international renewable energy industry claimed that a climate friendly solution was not trade barriers, but rather, it was to expand markets for PV panels, especially in China and other developing countries. This position was echoed by European climate NGOs, who argued that

At a time of economic crisis, concrete actions to grow EU-China low carbon markets would lower costs, create employment and generate momentum for greater mutual ambition in tackling climate change. (WWF et al. 2013).

Chinese NGOs, many of whom were supported by the EU through environmental protection cooperation projects, also argued that the dispute compromised their and also EU's efforts to promote green development in China (Chen and Bai 2013), notably by threatening 40,000 jobs there, which would strengthen the position of the powerful fossil fuel lobby and support those in China who opposed climate action as western plot to contain China's rise (Gou 2010). ${ }^{49}$

Moreover, it was clear, by the time the dispute erupted, that the Chinese central government was already taking measures to ramp up domestic PV installation capacity. The targets were raised consecutively from $21 \mathrm{GW}$ in 2011 to $35 \mathrm{GW}$ in 2013 to keep up with the speed of PV projects developments (Gao 2014). ${ }^{50}$ This rose prospects for a more balanced trade relationship and opportunities for further cooperation with EU companies. Furthermore, two new global initiatives emerged in parallel to build alternative mechanisms to manage trade frictions in the global renewable energy sector. First, the Semiconductor Equipment and Materials International (SEMI) launched an initiative in Brussels in February 2013 to establish a 'World Solar Council' (SEMI 2013). ${ }^{51}$ Secondly, a political initiative for a 'Global Agreement on Free Trade in Environmental Goods', launched at the 2011 APEC summit, was discussed at a series of hearings in the European Parliament in the spring of 2013. By 2014 the EU, China, and many other countries were ready to start negotiating a multilateral agreement that would "eliminate tariffs for goods we all need to protect our environment and address climate change", including PV panels. Several rounds of negotiations have followed and preliminary conclusions were reached at the G20 Summit in Shanghai in July 2016, even though negotiators failed to conclude the deal in December as foreseen (Sell 2017). ${ }^{52}$

\footnotetext{
49 These arguments prevailed amongst Chinese grassroots NGOs such as Greennovation Hub, who cooperated under EU-funded projects with the delegation in Beijing (Li. interview 21.02.2013). Antiwestern "low carbon imperialism" populist had gained a lot of credit in China in the aftermath of Copenhagen, with opuses like Gou's "Low Carbon Plot" (2010) selling volumes.

50 By 2014 the target was scaled up to $50 \mathrm{GW}$ and Chinese experts discussed a $100 \mathrm{GW}$ target for 2020.

51 Initiative presented in Brussels on 21 February 2013 in the presence of EU officials (Commission and European Parliament), industry representatives (SEMI, AFASE, EU-Prosun) and NGOs (WWF).

52 The "Joint Statement Regarding Trade in Environmental Goods", was signed at the World Economic Forum on 24 January 2014 in Davos. By 2016, 18 WTO members were negotiating on behalf of 46.
} 


\section{Conclusions: subsidization, green growth free trade and China}

The dispute on trade in solar PV brought the EU and China to the brink of a trade war. In Brussels, initially the dominant narrative was that the Chinese solar PV industry, with the support of 'state capitalism', was intent on eliminating competition through dumping to create a global monopoly for itself. From this perspective, trade defence was the only way to re-establish fair trade conditions for the European industry and promote a healthy development of the global PV industry. However, by the end of 2013, the political momentum for tariffs had weakened and a return to cooperative solutions was building up. The alternative narrative supporting this shift argued that Europe should instead harness China's comparative advantage to scale up PV panels production and consolidate industrial support for climate policy globally, while pushing for increased market access for European technology providers and market building policies for solar energy globally. In this view, trade protection was an outdated instrument, ill-suited to address the issues of the born global PV industry. Worse, it sent the wrong political signal for EU-China cooperation on climate change.

Ultimately, the Commission was convinced to make full use of the flexibility provided by its trade defence regulations to strike a political compromise, which enabled it to resume cooperation with China (De Gucht 2013b). As shown in the chronology provided early in Table 1, and in the Annexed list of cases, the legal actions that followed the price settlement, notably the withdrawal of the price undertaking for several Chinese companies, found in violation of the agreement, remained under the political radar. Then, in a complete reversal from earlier statements, a cross-political coalition of MEPs even called on the Commission to terminate the measures which 'armed the European PV market' in October 2015 (EP 2015). In 2016, the Commission decided to prolong, but also progressively phase out the duties to reflect the sharp decrease in PV prices globally.

The solar panel dispute thus showed a specific manifestation of a normative conflict between trade law and the environment, where measures aimed at protecting industries from the adverse impact of trade liberalization were questioned on the ground that they challenged government interventions that were deemed beneficial for the development of green technologies and the promotion of a capitalist low-carbon future. In the solar panel dispute, fending off China's 'state capitalism' may have been a bigger concern for European leaders than the Climate. But they disagreed on the best strategy to achieve this goal, considering the globalized and interdependent structure of the PV industry. Such tensions might be the essence of economic globalization. But the ability of existing trade rules to manage them was called into questions and the jury is still out on whether the solution lies with a free trade agreements for environmental goods, or nongovernmental initiatives such as the 'Global Solar Council' finally launched at the COP 21 in December 2015 (Sell 2017). ${ }^{53}$

\footnotetext{
53 http://www.globalsolarcouncil.org/. Accessed on 31.03.2016.
} 
Acknowledgements The present article has been written within the research project "EU-China Disputes on Trade Remedies, Climate Change and Natural Resources: A Legal Analysis for A Better Legal Framework and Cooperation", financed by the China-EU School of Law, under the scientific supervision of Prof. Elisa Baroncini.

Open Access This article is distributed under the terms of the Creative Commons Attribution 4.0 International License (http://creativecommons.org/licenses/by/4.0/), which permits unrestricted use, distribution, and reproduction in any medium, provided you give appropriate credit to the original author(s) and the source, provide a link to the Creative Commons license, and indicate if changes were made.

\section{References}

Bollen Y (2016) Unpacking member state preferences in trade policy—a research agenda. Unpublished Paper

Brown C (2013) Understanding China as a PV market. Solar Server. 9 December

Buchan D, Keay M (2015) Europe's long energy journey: towards an energy union?. Oxford University Press, Oxford

中国社会科学院 (CASS) (2013) 深度讨论:如何看待欧盟对华光伏反倾销案 (In-depth debate: how should we look at the EU solar panel anti-dumping case). Online. 10 June 2013

Chaffin J (2013) Karel De Gucht, Frustrated and Outflanked. Financial Time. 30 July. http://www.ft.com/ cms/s/0/aa79490a-f8f6-11e2-86e1-00144feabdc0.html

Chen J, Bai Y (2013) China-EU dispute could affect climate change cooperation. Chinadialogue. 12 June

China Economic Review (2013) China is the clear winner in the EU-sino solar dispute. China Economic Review. 30 July

Choudhury N (2013) Chinese accused of pressuring EU to oppose trade duties. PV-Tech. 28 May

Curran L (2015) The impact of trade policy on global production networks: the solar panel case. Rev Int Polit Econ 22(5):1025-1054

De Gucht K (2013a) Statement by the EU Commissioner on mobile telecommunication networks from China. MEMO 13/439 Brussels. 15 May

De Gucht K (2013b) Remarks on the decision to impose provisional anti-dumping measures on imports of solar panels from China. MEMO 13/499, Brussels. 4 June

De Gucht K (2013c) Statement on the amicable solution in the EU-China solar panel case. Memo/13/730. Brussels, 27 July

De Gucht K (2013d) Modernization of trade defence_-getting the job done'. Speech 13/889. Brussels, 7 November. http://europa.eu/rapid/press-release_SPEECH-13-889_en.htm. Accessed 14 Apr 2016

Dunford M, Lee HK, Liu W, Yeung G (2013) Geographical interdependence, international trade and economic dynamics: the Chinese and german solar energy industries. Eur Urban Reg Stud 20(1):1436

Economic Observer (2013) PV majors to dying market. Economic Observer English Edition. 25 January European Commission (2012a). EU initiates anti-dumping investigation on solar panel imports from China. MEMO 12/647. 6 September

European Commission (2012b) The EU's investigation into solar panel imports from China does not harm Europe's climate goals. Factsheet. 10 September

European Commission (2013a) Draft guidelines on union interest. DG Trade Working Document

European Commission (2013b) EU imposes provisional anti-dumping tariffs on Chinese solar panels. 4 June

European Commission (2014) Guidelines on state aid for environmental protection and energy 20142020. 28 June

European Parliament (2015) Call on the European Commission to remove trade barriers impacting imports of solar cells and modules from China. 2 October

EPIA (2015) EPIA calls for free and fair trade between Europe and China. 27 April

EU-Prosun (2012) EU-Prosun, the new sustainable solar energy initiative for Europe calls on the European Commission to investigate unfair trade practices by Chinese manufacturers. 26 July

EU-Prosun (2013) European Commission accepted illegal deal with China. 2 August

Evenett SJ (2013) China EU solar panel trade dispute: rhetoric versus reality. VOX. 5 June 
Evenett SJ, Vermulst E (2005) The politicisation of EC anti-dumping policy: member states, their votes and the european commission. World Econ 28(5):701-717

凤凰网 (Fenghuang Jingji Wang) (2012) 欧盟对华光伏产品反倾销立案 30 万从业人员将受㞲击 (EU Solar Panel Anti-Dumping Case- 300,000 jobs will be affected). 7 September 2012

Gallagher KS (2014) The globalization of clean energy technology-lessons from China. MIT Press, Cambridge

Gallagher KS, Zhang F (2013) Innovation and technology transfer across global value chain. Climate and Development Knowledge Network. July

Gao H (2014) China's renewable energy policy framework and development target. In: IGES-ERI policy research workshop, Beijing, 9 September

Gao Y (2012) Should China bailout its PV industry. Chinadialogue. 12 September

勾红洋 (Gou H) (2010) 低碳阴谋 中国与欧美的生死之战 (Low carbon plot-China's vital war with the UE and Europe) 山西经济出版社 (Shanxi Edition Publishing)

Goron C, Freeman D (2017) Industrial policy and climate change strategy: comparing China and the EU's path to the Paris 2015 United Nations Conference Agreement (COP21), upcoming in Telo, Mario, Wang, Xiaotong, Ding, Chun. The EU-China partnership. Bridging institutional, and ideational differences between two unprecedented global actors. Routledge

Guérin E, Schiavo J (2011) Chinese renewable energy and technology policies: legal compatibility with WTO rules and economic interactions with other countries climate and industrial policies. IDDRI. Paper no. 02/11, March

Grau T, Huo M, Neuhoff K (2011) Survey of photovoltaic industry and policy in Germany and China. Energy Policy 51:20-37

Green M (2011) A solar trade war could put us all in the dark. MIT Technology Review. 19 December

INTA. International Trade Committee, European Parliament (2012). Report on EU and China: unbalanced trade? (2010/2301 INI). 20 April

Klein N (2014) This changes everything. Capitalism versus the climate. Simon Schuster Publisher, New York

Kolk A, Curran L (2017) Contesting a place in the sun: on ideologies in foreign markets and liabilities of origin. J Bus Ethics 142(4):697-717

Laurent E (2013) Solar panels: a crisis made in China. Asia Centre, China Analysis, Special Issue, June

Lewis J (2014) The rise of renewable energy protectionism: emerging trade conflicts and implications for low carbon development. Glob Environ Polit 14(4):10-35

Martin D (2013) Duty calls? Parliament magazine. Issue 373. July

Moreira V, MEP (2012) Oral question, measures to protect the EU market from unusually low-priced imports of Chinese origin, especially photovoltaic panels (O-000162/2012). 24 September

南方日报 (Nanfang Ribao) (2013) 欧洲 20 多国超千企业要求放弃对华光伏征税” (Over 1000 enterprises from more than 20 European Countries ask to give up on imposing Solar Panel Tariffs) 11 April 2013

Nitzschke M (2013) China wants a solar monopoly. Deutsche Welle. 6 June

Nordström H (2011) The political economy of EU anti-dumping policy: decoding member states votes. Draft WTO paper. https://www.wto.org/english/res_e/reser_e/gtdw_e/wkshop11_e/nordstrom_e. pdf. Accessed 18 May 2017

Prognos (2013) The impact of anti-dumping and/or countervailing measures on imports of solar modules, cells and wafers from China on EU employment and value added, Basle, Berlin, February

PV magazine 9.04.2013. Euro PV companies petition EC over Chinese module tariffs

PWC (2013) Review of prognos study published in the course of the EU antidumping and anti-subsidy investigations on imports of photovoltaic products from China. May

Rubini L (2011) The subsidization of renewable energy in the WTO: issues and perspectives. Working paper no. 2011/32. June 2011

Sell M (2017) Climate and trade policy in a New Era: Options ahead. ICTSD opinion. http://www.ictsd. org/opinion/climate-and-trade-policy-in-a-new-era-options-ahead. Accessed 18 May 2017

SEMI (2013) Global trade war and peace: unified approaches to a global solar energy solution. White Paper. February

史燕君 (Shi Y) (2013) 中国光伏业已准备好贸易战 损失远超 3500 亿 (The Chinese industry is prepared for a trade war, the losses reach far beyond 350 Billion Yuan) 国际金融报 (International Financial Time) 6 June 2013

Snyder F (2001) The origins of "nonmarket economy: ideas, pluralism and power in the EC anti-dumping law about China. Eur Law J 7(4):369-434 
Solar Server (2013) EU member states approve negotiated solar trade deal between the EU and China. Solar Server, 8 August

Steinbach A (2014) Price undertakings in EU anti-dumping proceedings — an instrument of the past? J Econ Integr 29(1):165-187

Swedish National Board of Trade (SNBT) (2013) Targeting the environment, exploring a new trend in the EU's trade defence investigations, June

Van Rompuy E (2013) Remarks by president of the European Council Herman Van Rompuy following the 16th EU-China summit. EUCO 241/13. Beijing, 21 November

Vermust E, Gatta B (2012) Concurrent trade defence investigations in the EU, the EU's new anti-subsidy practice against China, and the future of both. World Trade Rev 11(3):527-553

Vermust E (2005) 10 major problems with the anti-dumping instrument in the European Community. J World Trade 39(1):105-113

Xie D (2013) Crisis for local economies as China's green energy sector crashes. Chinadialogue, 31 January

Xinhua (2013a) Commentary: EU solar duties targeting China could backfire, 9 May

Xinhua (2013b) EU-China solar panel deal advert crisis, Benefit World. 30 July

新浪网 (Xinlangwang) (2013) 光伏产品反倾销税-欧盟光伏挑事里外不讨好 (Stirring up dispute over solar PVs leads to lose-lose situation for the EU) 8 June 2013

王佑 Wang Y (2013) 107 亿负债吓退接盘方-尚德破产重整方案或延期出炉 (107 billion debt risks spreading-let Suntech go bankrupt and restructure or prolong the fire) 第一财经日报 (First Financial Times) 17 September 2013

Watson G (2012) Written question solar panels and the People's Republic of China (E-009610-12), 22 October

Wilke M (2011) Feed-in-tariffs for renewable energy and WTO subsidy rules. An initial legal review. ICTSD programme on trade and environment. Paper no. 4. November 2011

WWF International, Dutch environmental group Natuur \& Milieu, E3G, Change Partnership (2013) Position paper on the proposed punitive import tariffs on chinese solar panels, 30 March

\section{Interviews}

Chinese Mission to the European Union. Brussels. 27.11.2014

M. Mark Dober, Consultant at Ellwood Atfield, Campaigner for EU-Prosun. Skype. 2.12.2014

Ms. Li Lina, Greenovation Hub. Beijing. 21 February 2013

M. Graham Watson, Member of the European Parliament, Brussels. 26.11.2014 